\title{
IAMJ
}

INTERNATIONAL

AYURVEDIC

MEDICAL JOURNAL

\section{A REVIEW STUDY ON MENTAL HEALTH - THE ROLE OF DIFFERENT PERSPEC- TIVES OF AYURVEDA DURING COVID-19 PANDEMIC}

\author{
Bhushan Raghuwanshi ${ }^{1}$, Ashwini Fulzele ${ }^{2}$, Dnyanesh Joshi ${ }^{3}$, Sneha Dhakite ${ }^{4}$ \\ ${ }^{1}$ Assistant Professor, Department of Kayachikitsa, DRGACH \& RC, Amravati, Maharashtra, India \\ ${ }^{2}$ Associate Professor, Department of Kayachikitsa, DRGACH \& RC, Amravati, Maharashtra, India \\ ${ }^{3}$ Associate Professor, Department of Samhita Siddhant, DRGACH \& RC, Amravati, Maharashtra, India \\ ${ }^{4}$ PG Scholar, Department of Kayachikitsa, MGACH \& RC, Salod (H), Wardha, Maharashtra, India
}

Corresponding Author: bhushanraghuwanshi8@gmail.com

\section{https://doi.org/ $10.46607 /$ iamj2208082020}

(Published online: August 2020)

Open Access

(C) International Ayurvedic Medical Journal, India 2020

Article Received: 16/07/2020 - Peer Reviewed: 04/08/2020 - Accepted for Publication: 04/08/2020

\section{Check for updates}

\section{ABSTRACT}

Currently all of us are experiencing emotions, thoughts, \& situation which we never have experienced before. The entire world had experienced many of the pandemics, particularly plague outbreak has been known immemorial. In 19th century, cholera pandemic followed by flu pandemics were highlights. In 20th century, subsequently, there have been outbreak of Asian flu, SARS, Ebola etc, but the pandemic of COVID -19 is on completely different platform. It has shaken the whole world with global health crisis. This pandemic of COVID has been locked each $\&$ every individual where they were $\&$ day by day number of patients are getting hiked which have given rise to feeling of fear of getting infected, feeling of fear of getting quarantined, fear of loss of profession, fear of losing jobs etc. Along with, response to lockdown, pandemic has created significant \& variable psychological impacts on many more individuals resulting in increased tendencies for suicidal attempts. Here in this review article the efforts are being made to compile the different perspectives of Ayurveda which can be implemented in management of different psychological conditions. Different treatment protocols through ayurvedic principle can be administered in psychological management during this COVID - 19 Pandemic. Considering the psychological 
impact of COVID-19 on individuals, Ayurveda can prove to be beneficial in this Pandemic with regards to prevention \& adjuvant therapeutic management with COVID-19 management protocol.

Keywords: COVID-19, Pandemic, Psychological impact, Ayurvedic perspective, etc.

\section{INTRODUCTION}

The COVID-19 is defining global health crisis of current time and the greatest global humanitarian challenge the world has to face. In March 2020, WHO made the assessment that COVID-19 can be characterized as a pandemic. The Global Physical-mental health and economic impact have been deranged. India has moved quickly, implementing a proactive, nationwide, lockdown, with the goal of flattening the curve and using the time to plan and resource responses adequately. And to combat with COVID-19, Indian Government extending the days of lockdown as required. With strong preventive measures and restrictions by the Indian Government in the form of lockdown, the citizens are going through a range of psychological and emotion reactions, fear and uncertainty being one of them. As these can be difficult times for all of us as we are hearing about spread of COVID-19 from all over the world, through television, social media, newspapers, family and friends and other sources. The most commonly faced emotion by all is Fear. It makes us anxious, panicky and can even possibly make us think, say or do things that we might be not doing under normal circumstances.

Lockdown is meant to prevent the spread of infection from one person to person, to protect ourselves and others. This means, not stepping out of the house except for necessary or emergency needs and ideally only a single, healthy family member making the trips when absolutely necessary. And staying at home can be quite nice for some time but can also be boring and feels restricting. Which can be results in the effecting the mental health of common human being. Ayurveda defines health as a state of equilibrium of tridosha, trimala, sapatadhatu and homoeostasis of mind as well as sense organs. And as Psychiatric illnesses are fundamentally not differing in physical illness.

As Acharyas explains the Manas (Mind) is considered three dimensional in terms of three Gunas viz. Satva,
Rajas and Tamas. Out of these three, Sattva is the state of pure mind with absolute balance when other two extreme qualities of mind viz. Rajas and Tamas. If Satva is in good state, it generates positive feelings but if not, then the body-mind relationship gets imbalanced leading to pradnyaparadh. ${ }^{1}$ It is believed that mainly mental illnesses are because of the disturbance of rajas and tamas, which can be cause due to continue restrictions, anxious and panicky situations. Mental illness is a broad term which includes almost all the disorders of mood behaviour which caused by faulty perception, emotion, thinking and attitude. Such behaviors range from mild irritation to severe forms of anxiety and depression.

In spite of lots of advancement in the science of psychiatry for decades the problems with the management of a certain mental problems have remained unsolved. In addition to this, adverse effects of anti-psychotic, anxiolytic medications are creating discomfort in the patient's mind. Yoga\& different Ayurvedic modalities help us in handling such type of mental disorders very effectively without side effects.

Three basic forms of mood disorders ${ }^{2}$ :

1. Major depressive disorder - may be due to persistent social distancing from their close ones, which may cause changes in sleep, appetite, energy level, concentration, daily behaviour or self-esteem.

2. Dysthymic disorder: A type of a chronic \& mild depression. It may be due to persistent social distancing and anxious-panicky surrounding situations, which may cause low mood status occurring for at least two years, along with at least two other symptoms of depression.

3. Bipolar disorder: It is also known as manic depression. It has episodes of mood swings ranging from depressive lows to manic highs. Manic episodes may include symptoms such as high energy, reduced need for sleep and loss of touch with reality. Depressive 
episodes may include symptoms such as low energy, low motivation and loss of interest in daily activities. Causative factor is continuing stressed environment like hearing about spread of COVID-19.

These all three forms of mood disorders collectively cause depressed state of mind due to fear, loneliness, socially distanced from the relatives, friends and work place, etc. and behavioural changes may ranging from sudden mood swings to gradual long lasting low energy state of mind and loss of interest in routine work.

Table 1: Different causes of Depression in COVID-19 Pandemic Situation and its Ayurveda perspective ${ }^{3}$ : -

\begin{tabular}{|c|c|c|}
\hline Sr. No. & Causes of Depression & Ayurveda Perspective \\
\hline 1. & $\begin{array}{l}\text { Diet Related - } \\
\text { - Lack of availability of nutritious food } \\
\text { - Unable to reaching out for craving food } \\
\text { - Snack food } \\
\text { - Uncalculated diet }\end{array}$ & $\begin{array}{l}\text { Aaharaj- } \\
\text { - TamasikAahar } \\
\text { - Improper dietary habits like Samashana, } \\
\text { Adhvashana Vishamashana. These may cause } \\
\text { Vishada because of Pragya-paradha. } \\
\text { - Overeating }\end{array}$ \\
\hline 2. & $\begin{array}{l}\text { Lifestyle Related - } \\
\text { - } \quad \text { Lack of physical and mental exercise. } \\
\text { - } \quad \text { Disturbed routine work } \\
\text { - Overuse of mobiles \& electronic, internet etc. } \\
\text { - Over sleeping } \\
\text { - } \quad \text { Seeking to virtual lifestyle }\end{array}$ & $\begin{array}{l}\text { Viharaj- } \\
\text { - Avyayam, Ekasan, } \\
\text { - Absence of physical and mental challenges }\end{array}$ \\
\hline 3. & $\begin{array}{l}\text { Psychological - } \\
\text { - livelihoods, not being Feel stressed and worried be- } \\
\text { cause all being afraid of } \\
>\quad \text { Falling ill and dying } \\
>\quad \text { Avoiding to approach health facilities due to fear of } \\
\text { becoming infected } \\
>\quad \text { Losing work during isolation, and of being dismissed } \\
\text { from work. } \\
>\quad \text { Being socially excluded in quarantine. } \\
>\quad \text { Feelings of helplessness, boredom, loneliness and } \\
\text { depression. } \\
\text { Being treated as an outcaste or blamed for spreading } \\
\text { the disease } \\
\text { - Rumours or fake news give wrong information and } \\
\text { spreads the fear } \\
\text { More watching, reading or listening to news about } \\
\text { COVID-19 feels anxious and stressed. } \\
\text { Unable to express feeling such as fear and sadness } \\
\text { by children }\end{array}$ & $\begin{array}{l}\text { Manasik- } \\
\text { - } \quad \text { Bhaya (Fear) } \\
\text { - } \quad \text { Shoka (Grief) } \\
\text { - } \quad \text { Kama } \\
\text { - } \quad \text { Chinta (Stress) }\end{array}$ \\
\hline
\end{tabular}

Overview on Some research contribution in the Management techniques with Ayurveda Perspective-

Many Studies contributed for the significant scientific exploration of this branch of Ayurveda. Different studies through extensive Multi-centric Clinical trials have evaluated efficacy of certain single as well as multi drugs therapies and Yoga-Pranayam techniques on various mental problems like Brahmyadi Yoga for Schizophrenia, Dhara Chikitsa in the management of 
Cittodvaga (Anxiety Neurosis), Manasa Mandata (Mental Retardation), Vataja shirahshula (Psychogenic Headache) and so on Some of these given below -

- A single Case Study on Brahmi ghrita \& Panchkarma ${ }^{4}$ :

With planned panchakarma initiation with DeepanaPachana and Udavartana (Powder massage) followed by internal oleation, therapeutic purgation and samsarjana krama. After then internal medicines and Nasya (Pratimarsanasya) with Brahmi ghrita was advised for one month without withdrawing on-going AED. Marked improvements were observed after Panchakarma in severity of attack, frequency of attack, duration of attack and postictal features.

- A Single Case Study on Apasmara ${ }^{5}$ -

Bramhi Vati \& with planned panchakarma initiation with Deepana-Pachana and Yoga Basti (enema), Shirodhara (Pouring of medicated oil from the distant height), Nasya along with Palliative medication for 1 month. Due to which patient is symptomless and feels relaxed.

Panchakarma and internal Ayurveda medicines work surprisingly in Cognitive impairment in this area. Shirodhara makes satiety in head, removes facial wrinkles, Santarpana of Indriya (nourishes all sense organs), and does the Pratipurana of Shiras and acts as Nidra Labha Sukha (gets good sleep easily and feels happy). Simultaneously it reduces the stress and stimulates nervous system. Nasya with PanchagavyaGhrita showed an anticonvulsant effect against maximal electroshock seizure .It also controls the regular occurrence of convulsions and the extent of duration and it does not have any side effect; hence, it can be prescribed for a long time in therapeutic dosage.

In Bramhi Vati, Brahmi being a Medhya (brain tonic) drug is recommended for various psychosomatic and psychiatric disorders. It increases immunity, memory, voice quality, feelings of joy, and satisfaction as well.

\section{- Mandukparni (Centella asiatica) (CA) - Generalised Anxiety Disorder ${ }^{6}$ :}

The clinical study of $70 \%$ hydro-ethanolic extract of Centella asiatica (CA) on generalized anxiety disorder (GAD) was conducted with the CA in a fixed dose regime (500 mg/capsule, twice daily, after meal). The Clinical trial revealed that, administration of $C$. asiatica regularly for two months reduced stress, attenuated anxiety, negated depression and enhanced adjustment and attention in patients without any side effects like vertigo, nausea, and dizziness or mental weakness. The treatment also helped in mental overwork in daily life. These observations clearly indicated that CA has potential action in the regulation of hypothalamopituitary-adrenocortical axis (HPA axis) especially, during stress related disorders. It appears that $C$. asiatica may be a safer alternative to Benzodiazepines for the therapy of stress related clinical disorders. The observations revealed that, CA not only significantly $(p<0.01)$ attenuated anxiety related disorders but it also significantly $(p<0.01)$ reduced stress phenomenon and its correlated depression.

- Bramhi (Bacopamonniera) extract in ageassociated memory impairment ${ }^{7}$ :

A double-blind, placebo-controlled randomized study in which subjects received either $125 \mathrm{mg}$ of SBME (standardized Bacopamonniera extract) or placebo twice a day for a period of 12 weeks followed by a placebo period of another 4 weeks (total duration of the trial 16 weeks). Each subject was evaluated for cognition on a battery of tests comprising mental control, logical memory, digit forward, digit backward, visual reproduction and paired associate learning. SBME produced significant improvement on mental control, logical memory and paired associated learning during the 12-week drug therapy.

- Ashwagandha (Withania somnifera) in moderate to severe Anxiety ${ }^{8}$ :

A randomised control trial study aimed on Employees with moderate to severe anxiety of longer than 6 weeks duration were carried out based on age and gender, to receive naturopathic care (NC) in one group \& standardized psychotherapy intervention (PT) in another group over a period of 12 weeks. Participants in the NC group received dietary counselling, deep breathing relaxation techniques, a standard multivitamin, and the herbal medicine, Ashwagandha (Withania somnifera) $300 \mathrm{mg}$ b.i.d. standardized to $1.5 \%$ with anolides, prepared from root. The PT inter- 
vention received psychotherapy, and matched deep breathing relaxation techniques, and placebo. Interpreted to Group comparison demonstrated a significant decrease in anxiety levels in the NC group over the PT group. Significant improvements in secondary quality of life measures were also observed in the NC group as compared to PT.

\section{- Ashwagandha- for Bipolar Disorder':}

A randomized, placebo controlled, add on treatment trial of Sensoril ${ }^{\circledR}$ (added to on-going prescribed pharmacological mood stabilizer) a Standardized Extract From a Medicinal Plant - (Withania Somnifera) for Cognitive Enhancement on Up to Seventy-six subjects with DSM IV bipolar I disorder for a period of 8 weeks appears to improve auditory-verbal working memory (digit span backward), a measure of reaction time, and a measure of social cognition in bipolar disorder.

\section{- Jatamansi Ghana Vati \& Bhastrika Yogic Kriya in Insomnia ${ }^{10}$ :}

Study described the re-establishment of the Ratriswabhava-prabhava Nidra, which is natural and according to biological clock by Bhastrika yogic kriya which is the non-medicinal remedy of lifestyle diseases like insomnia. 30 clinically diagnosed and confirmed patients of Insomnia were selected and randomly divided into following three groups.

Group 1 was recommended bhastrika kriya for 15-20 min. after performance of sukshma vyayama for 45 days.

Group 2 was recommended "jatamansi Ghana vati" in the dose of $4 \mathrm{gm}$. / day in two divided doses (2 tablets x.b.d.s.) with Lukewarm water for 30 days as ayurvedic therapy.

Mixed Group 3 - recommended bhastrika yogic kri$y a$ for 15-20 min. after performance of sukshma vyayama along with jatamansi Ghana vati simultaneously for 45 days and 30 days. Results in significant improvement in sleep pattern and symptoms of all the patients by Bhastrika pranayama as well of jatamansi Ghana vati in the same manner. Thus, we can say that Bhastrika pranayama alone may diminish these above symptoms because it not only produces symptomatic improvement.
- Jatamansi Siddha Taila Shirodhara on Anxiety neurosis ${ }^{11}$ :

In this clinical trail 60 patients of Anxiety Neurosis were selected and divided into two groups of 30 patients each and given Shirodhara by Jatamansi siddha taila and Tila Taila for 14 days. Patients were evaluated with Haailto's AAiett Rating scale. Result of Shirodhara by Jatamansi Siddha Taila proved to be good treatment modality in the view of long-term relief of Anxiety Neurosis as it acts by strengthening Manovaha srotasa.

\section{- Tagara (Valerianawallichii DC.)} and Jatamansi ${ }^{12}$ :

A Comparative Clinical Study was done to evaluate the effect of Tagara (Valerianawallichii DC.) and Jatamansi (Nardostachys jatamansi D C.) in the management of Anidra. A total of 34 patients of primary insomnia were randomly selected from Out $\mathrm{Pa}$ tient Department and In Patient Department of Manasa Roga and assigned into two groups, wherein 30 patients completed the study (15 in each). Tagara Churna (powder of $V$. wallichii) and Jatamansi Churna (powder of $N$. jatamansi) in the dose of $4 \mathrm{gm}$ with milk for each group respectively was administered three times a day for a period of 1 month. Results both the groups showed good results, but Tagara group showed better results in comparison to Jatamansi group.

\section{- Sudarshan Kriya yoga ${ }^{13}$ :}

This study is finding association between emotional disorders and vagal tone as indicated by heart rate variability. Yogic breathing is a unique method for balancing the autonomic nervous system and influencing psychology and stress related disorders. This study shows Sudarshan Kriya yoga, a sequence of specific breathing technique can alleviate anxiety, depression, stress, post-traumatic stress and stress related medical illness.

- The effects of yoga on stress ${ }^{14}$ :

A systematic literature search was performed to identify randomized controlled trials (RCTs) and clinical controlled trials (CCTs) that assessed the effects of yoga on stress management in healthy adults. The systematic review was based on eight RCTs and CCTs 
that indicated a positive effect of yoga in reducing stress levels or stress symptoms. This review revealed positive effects of yoga on stress reduction in healthy adult populations.

\section{DISCUSSION}

According to the World Health Organization (WHO), "Mental health is a state of well-being in which an individual understands his or her own capabilities, can deal with the normal worries of life, can perform work effectively, and is able to take participation to their communities." While explaining the concept of Swasthya, Ayurveda has also included attributes of mental health such as - A healthy balanced and pleasing state of mind, Being happy and courteous, Proper and pleasing sleep, Steady and well balanced mental faculties, Pleasant and energetic state of physical characteristics, Control over Dharaniya Vega like Kama (lust), Krodha (anger), Bhaya (fear), Irshya (unkindness), Shoka (grief), Lobha (greediness) and Moha (obsession) ${ }^{15}$

Ayurveda has mentioned three types of Chikitsa i.e. Daivavyapashraya Chikitsa (heavenly or spiritual treatment), Yuktivyapashraya Chikitsa (logical treatment), and Satwavajaya Chikitsa (psychotherapy), for treating mental illnesses as well. ${ }^{16}$ The concept of Satvavajaya Chikitsa in Ayurveda is centred on the concentration by cheering positive vibes to the person. Ayurveda have faith in an individual as a whole, encompassing body and attention together and treatment is also aimed for both. Some health diseases such as psoriasis, eczema, auto immune diseases, blood pressure etc are supposed to be prone to get worse by mental factors such as anxiety and stress disorders.

Manasika Vyadhi can be classified according to Dosha engrossment and seat of manifestation. The classifications can be as Mano Adhisthita Manasika Vikara i.e. Mental disorders where Manodoshas are solitary basically involved. E.g. Kama, Krodha, etc. Nanatmaja Manasa Vikara i.e. endogenous psychological illnesses caused by specific Sharirika dosha. E.g. Bhrama, Tandra, etc. Sharira Mano Adhisthita Manasika Roga i.e. Mental illnesses where both Sharirika and Manodoshas are fundamentally in- volved. E.g. Unmada, Apasmara, etc. Mano Shariradhisthita Manasa Roga i.e. Disorders basically caused by affliction of Manodoshas afterward leading to the involvement of the Sharirika doshas. E.g. Bhayaja Atisara, Shokaja Jwara, etc. Behavioural disorders like sexual perversions e.g.

Kumbhika, Asekya etc. ${ }^{17}$ This definitely help to understand that Ayurvedic manuscripts describe a range of mental disorders, which seem to include all kinds of anxious, psychotic, incontrollable and personality disorders as known today. As the disease developed, concerns regarding health, economy, and means of support increased day-to-day.

The COVID-19 pandemic is bringing significant challenges to people, families, communities and countries result in mental health activity such as mood disorder. A mood disorder is a mental health issue that primarily disturbs an individual's emotional state. It is an illness in which an individual experiences long stages of exciting happiness, dangerous sadness, or both. Mood disorders can cause changes in your behaviour and can affect your ability to deal with routine activities, such as work. Depression is a common mental disorder. Grief or sadness is a characteristic response to a distressing life incident or crisis. ${ }^{18}$

There are several different types of depression. Symptoms may fluctuate depending on the types of the disorder. Persistent depressive disorder (dysthymia), Seasonal affective disorder (SAD), Psychotic depression, Depression related to a medical condition, medication, or substance abuse. Bipolar disorder is demarcated by swings in mood from stages of depression to mania. When an individual experience a low mood, symptoms may tolerate a resemblance to those of a clinical depression. Depressive episodes alternate with manic episodes or mania. During a manic incident, an individual may feel ecstatic or can also feel shorttempered or have increased levels of activity.

\section{CONCLUSION}

COVID-19 epidemic has caused a lot of indecisiveness in the lives of public, just like their global counterparts. The influences that predicted higher influence 
were younger age, being female and those having a known physical comorbidity. There is a necessity for considering mental health issues by planning interventions to fight the epidemic. To encourage mental health and prevent illness, there is a need to generate such alive conditions and environment that support mental health and allow people to adopt and maintain fit lifestyle. Various studies have been conducted on the ill effects of mental health like stress, anxiety, psychological disorders, etc on which Ayurveda proven to be effective in the prevention and management. The consumption of healthy 'Ahara' and adhering to the principles of 'Dinacharya', 'Ritucharya', 'Sadvritta' \& 'Achara Rasayana' are the fundamental things which play a fundamental role in attaining positive mental health.

\section{REFERENCES}

1. Bramhanand Tripathi, Varanasi, Edition 2016, Chaukhamba Surbharati Prakashan, Charak Samhita, Sharir Sthana, Cha 1, Page No. 795.

2. Https://En.Wikipedia.Org/Wiki/Mood_Disorder

3. Kashinath Pandey, Gorakhnath Chaturvedi, Varanasi, Chaukhamba Bharti Academy, Charak Samhita, Nidan Sthana, Unmad Nidan, Cha. 7, Page No. 656

4. Rajdip R Rao Et Al: A Case Of Guillain-Barre Syndrome (Mans Gatavata) Cured With Mustadi Yapan Basti

5. Sawarkar, Gaurav \& Sawarkar, Punam. (2020). Role Of Ayurveda In The Management Of Apasmara: A Case Study. Journal Of Indian System Of Medicine. 10.4103/JISM.JISM_63_19.

6. Jana, U., Et Al. "A Clinical Study On The Management Of Generalized Anxiety Disorder With Centellaasiatica." Nepal Med Coll J 12.1 (2010): 8-11

7. Raghav S, Singh H, Dalal P K, Srivastava J S, Asthana O P. Randomized Controlled Trial Of Standardized Bacopamonniera Extract In Age-Associated Memory Impairment. Indian J Psychiatry 2006; 48:238-42

8. Cooley K, Szczurko O, Perri D, Mills EJ, Bernhardt B, Et Al. (2009) Naturopathic Care For Anxiety: A Randomized Controlled Trial ISRCTN78958974. Plos ONE 4(8): E6628. Doi:10.1371/Journal.Pone.0006628)

9. Chengappa KN, Bowie CR, Schlicht PJ, Fleet D, Brar JS, Jindal R. Randomized Placebo-Controlled Adjunctive Study Of An Extract Of Withania Somnifera For Cognitive Dysfunction In Bipolar Disorder. J Clin Psychiatry.

Doi: $10.4088 / \mathrm{JCP} .13 \mathrm{~m} 08413$
10. Dr. R. S. Ranawat, Prof. N. S. Chundawat, A Comparative Study Of Bhastrika Yogic Kriya And Jatamansi Ghana Vati In The Management Of Insomnia, Journal Of Ayurveda, Vol.V No.4 Oct-Dec 2011, Page No 5257

11. Anup Jain, Surendra M. Vedpathak, Ashok Kumar Singh, Arun Gupta, Umesh Sapra. Clinical Evaluation Of Jatamansi Siddha Taila Shiro-Dhara On Anxiety-Neurosis, J Of Ayurveda And Hol Med (JAHM).2016;4(2):16-25.

12. Toolika E, Bhat NP, Shetty SK. A Comparative Clinical Study On The Effect Of Tagara (Valeriana Wallichii DC.) And Jatamansi (Nardostachys Jatamansi DC.) In The Management Of Anidra (Primary Insomnia). Ayu. 2015;36(1):46-49. Doi:10.4103/09748520.169008

13. Brown, Richard \& Gerbarg, Patricia. (2005). Sudarshan Kriya Yogic Breathing In The Treatment Of Stress, Anxiety, And Depression: Part INeurophysiologic Model. Journal Of Alternative And Complementary Medicine (New York, N.Y.). 11. 189201. 10.1089/Acm.2005.11.189.)

14. Chong CS, Tsunaka M, Tsang HW, Chan EP, Cheung WM. Effects Of Yoga On Stress Management In Healthy Adults: A Systematic Review. Alternther Health Med. 2011;17(1):32-38.)

15. Acharya "Charakasamhita", Nirnayasagar Press, Bombay, 383-384. (1941).

16. Chatterjee-Acharya Paradhkar., "My Experiments With Cuckoo Meat", Journal Of Research In Indian Medicine, Vol. VII, No.2, 79 To 81. (1972)

17. Charak Samhita, Chakrapani Commentary By Acharya J.A., Sutrasthana, Dirghajivitiya Adhyay 7, Verse 27, Varanasi: Chaukhamba Surbharati Prakashana; 2000, P.50

18. Fairchild, K., \& Scogin, F. (2008). Assessment And Treatment Of Depression. In K. Laidlow \& B. Knight (Eds.), Handbook Of Emotional Disorders In Later Life: Assessment And Treatment. New York, NY: Oxford University Press.

\section{Source of Support: Nil \\ Conflict of Interest: None Declared}

How to cite this URL: Bhushan Raghuwanshi et al: A Review Study On Mental Health - The Role Of Different Perspectives Of Ayurveda During Covid-19 Pandemic. International Ayurvedic Medical Journal \{online\} 2020 \{cited August, 2020\} Available from: http://www.iamj.in/posts/images/upload/4174_4180.pdf 